\title{
Resertch Article: Effect of rainfed organic cotton on chemical properties in vertisol
}

\section{LEENA D. KARANGAMI, S.M. BHOYAR, MANCHALA SANTHOSH KUMAR, P.W. DESHMUKH AND NAMDEO DHURVE}

Article Chronicle : Received : 11.07.2017;

Accepted :

26.07.2017

KEY Words :

Cotton, Rainfed, pH, EC, Organic Carbon, Total nitrogen

Author for correspondence :

\section{LEENA D.}

\section{KARANGAMI}

Department of Soil

Science and Agricultural

Chemistry, Post

Graduate Institute, Dr.

Panjabrao Deshmukh

Krishi Vidyapeeth, AKOLA (M.S.) INDIA

See end of the article for authors' affiliations
SUMMARY : The present investigation entitled "Effect of rainfed organic cotton on chemical properties in Vertisol" was conducted at the farm of Cotton Research Unit, Central Research Station, Dr. Panjabrao Deshmukh KrishiVidyapeeth, Akola, during Kharif 2015-16. The experiment was laid out in RBD with ten treatments and three replications. Organic sources used were FYM, Vermicompost, Sunhemp, Castor cake, Neem cake and Sunhemp as in situ green manure crop. After $6^{\text {th }}$ year of organic cotton experimentation, the influence of different organic sources application of FYM @ $10 \mathrm{t} \mathrm{ha}^{-1}$ reported lowest $\mathrm{pH}$ of soil (7.86) and same dose of FYM application reported numerically lowest value of EC $\left(0.115 \mathrm{dSm}^{-1}\right)$, whereas significantly highest organic carbon $(0.57 \%)$ content of soil was recorded by the treatment vermicompost @ $5 \mathrm{t} \mathrm{ha}^{-1}$, and the significantly total nitrogen content of soil was recorded by the treatment FYM @ $10 \mathrm{t} \mathrm{ha}^{-1}$. Significantly lowest C:N ratio of soil (8.24) was recorded by the treatment received FYM @ $10 \mathrm{tha}^{-1}$.

How to cite this article : Karangami, Leena D., Bhoyar, S.M., Kumar, Manchala Santhosh, Deshmukh, P.W. and Dhurve, Namdeo (2017). Effect of rainfed organic cotton on chemical properties in vertisol. Agric. Update, 12(TECHSEAR-4) : 912-916; DOI: 10.15740/HAS/AU/12.TECHSEAR(4)2017/912-916. 